\title{
Exploring nursing student engagement in the learning environment for improved learning outcomes
}

\author{
Melba Sheila D'Souza ${ }^{1}$, Chandrani I sac ${ }^{1}$, Ramesh Venkatesaperumal ${ }^{1}$, K Subrahmanya Nairy $^{2}$, \\ Anandhi Amirtharaj ${ }^{1}$ \\ 1. Department of Adult Health and Critical Care, College of Nursing, Sultan Qaboos University, Muscat, Sultanate of Oman. \\ 2. Department of Business and Financial Studies, Higher College of Technology, Al Khuwair, Muscat, Oman. \\ Correspondence: Melba Sheila D'Souza. Address: Department of Adult Health and Critical Care, College of Nursing, \\ Sultan Qaboos University, Muscat, Sultanate of Oman. Email:melba123@rediffmail.com
}

Received: J une 6, 2013

DOI : $10.5430 /$ cns.v2n1p1

Online Published: October 14, 2013

Accepted: September 27, 2013

URL: http://dx.doi.org/10.5430/cns.v2n1p1

\section{Abstract}

Background: Nursing students' engagement in the curriculum is important for learning outcomes in undergraduate nursing education.

Objective: The aim of this paper is to explore students' engagement processes in cognitive, behavioural and emotional learning in the undergraduate nursing curriculum.

Method: An exploratory cross-sectional research design was used to conduct the study in Oman. A standardized validated Student Engagement Questionnaire (SEQ) was used to collect data from 250 nursing students of a public nursing school in 2010.

Results: $50 \%$ of the students ( $\mathrm{N}=250)$ had high mean scores in the three engagement domains: Meaningul processes, Participation and Focused attention. Participation mean scores were the highest compared to the Focused attention and Meaningul processes. There was a significant association between cohort, as well as siblings studying in the same university and the 17 engagement subdomains.

Conclusions: Nursing students showed higher engagement in the clinical learning environment. Critical and creative thinking, adaptability, ability to solve problems and to manage one's own learning were considered important factors in the cognitive and behavioural learning process. The ability to work with others, communication and interpersonal skills are considered vital for emotional and behavioural learning.

Implications: Nursing students should be engaged in student centered and interactive pedagogies for cognitive, emotional and behavioural learning. Nurse educators should integrate active and collaborative learning strategies in teaching.

\section{Key words}

Nursing education, Student engagement, Active learning, learning environment, Baccalaureate nursing

\section{I ntroduction}

In the undergraduate nursing curriculum students gain knowledge and learn to appreciate the values of a broad range of biomedical, basic, social and human sciences, and the depth of knowledge that exists within each nursing specialty. There 
has been a paradigm shift in the teaching learning approaches in recent years, which has moved away from teacher centered to student centered learning. It has been found that $40 \%-60 \%$ students have no active participation in school as they progress from elementary onto middle and then to high school ${ }^{[1]}$ and perceive lack of opportunities ${ }^{[2,3]}$. Low engagement in learning among students leads to dissatisfaction, negative experience, and rise in drop outs ${ }^{[4-6]}$. Though nursing students were engaged in rigorous curricula, they do not perceive engagement in student-centered and interactive pedagogies ${ }^{[7]}$. Also, a lack of engagement in direct patient care inhibits student's ability to achieve learning objectives in the learning environment ${ }^{[8]}$. The learning environment refers to the social, psychological and pedagogical contexts in which learning occurs, which affects student achievement and attitudes and to the contextual factors which influence the way that learning is approached ${ }^{[9,10]}$.

There exists a clear link between high motivation and engagement in clinical learning and increased levels of student's academic success in a variety of ways ${ }^{[11-14]}$. Engaged students earn better grades and exhibit increased practical competence along with the ability to transfer their skills to new situations ${ }^{[15]}$. Increased nursing student engagement occurs with purposeful academic activity and is associated with a greater ability to pursue ideas independently and synthesize information, and this in turn leads to a desire to learn on one's own ${ }^{[16,17]}$. Nursing student engagement is defined as students' willingness to actively participate in the clinical learning process, exhibiting tangible behaviours in the class or clinical environment ${ }^{[4]}$ or outside the class ${ }^{[18]}$. A National survey of student engagement (NSSE) study among 3000 randomly selected students in nursing, health professions and teaching majors revealed that nursing profession majors perceived significantly less engagement in active and collaborative learning than their peers in education majors. $83 \%$ of the nursing students were significantly more academically challenged $(p<0.001)$ than their peers in education and other health profession majors ${ }^{[7]}$. The novice learner introspects, internalizes and applies his/her intellectual capabilities (e. g. information technology, safety, competency, knowledge, attitude, behaviours) in the learning environment ${ }^{[17,}$ 19]

\section{Background}

The baccalaureate nursing education program at the College of Nursing $(\mathrm{CON})$ is based on six competencies; patient centered care, teamwork and collaboration, evidence-based practice, quality improvement, informatics, and safety built in line with international nursing standards ${ }^{[20,21]}$. This program has two tracks of entry: the direct entry (pre-licensure) level who register for the regular Bacheleor of Science in Nursing (BSN) and the RN/post-licensure level who register for the Nursing diploma graduate program (NDGP). The BSN has 130 credits and the NDGP has 67 credits incorporating core, basic biomedical and behavioural sciences, nursing specialties (e.g. adult health, psychiatric mental health, maternal, child health, community health, critical care, administration), complementary and advanced courses with residential practice for preparing professional Omani nurses. The curriculum and instructional processes of the BSN program are based on sound educational principles, which synthesize principles of adult learning and educational pedagogy. The course content, objectives, learning activities and assessment-evaluation are designed to achieve the student learning outcomes. A variety of interactive pedagogies (group discussion, projects, case scenarios, simulation, e-learning, e-portfolio, evidence based practice, simulation, reflective practice and concept maps) are used to promote student centered learning and achievement of course objectives. Nursing students are expected to provide high standards of care using clinical reasoning defined as the process of applying knowledge and expertise to a clinical situation to develop a solution ${ }^{[22]}$, decision-making, communication, application of knowledge in a challenging clinical environment. The nurturing of these generic and specific intellectual capabilities largely depends on the processes of student engagement involving cognitive, emotional and behavioural learning.

If students do not participate or engage in the learning environment, they do not use the interactive technologies and clinical resources available. This leads to an unrealistic expectation of the student to transit from novice to expert learner or being a safe effective student nurse. This growing gap between theory and practice has been a subject of concern to nurse educators and practitioners. There is a need for development of higher capabilities like clinical reasoning, judgment, integrating theory into practice, participation in clinical, teacher encouragement and cooperative student-student interaction among undergraduate nursing students in Oman. Little research exists on how nursing student engagement is 
influenced by their perceptions of the teaching-learning environment (e.g. knowledge base, motivational context, learner activity, interaction with others) for improved learning outcomes in the Middle East. This study explores the processes of student engagement in cognitive, behavioural and emotional learning in the undergraduate curriculum in Oman.

\subsection{Literature review}

Review studies show that student engagement makes a difference in student outcomes, adjustment to school, retention, including the development of cognitive and intellectual skills and life-long learning ${ }^{[23,24]}$. There was significant mean difference in the examination scores between of the two groups (structured group discussions and purely didactic) of students in subsequent medical-surgical nursing courses in a quasi-experimental study ${ }^{[25]}$. Transferring knowledge and the effectiveness of clinical teaching-learning strategies lies in facilitating student engagement through promoting a diversity of experiences, creating shared learning opportunities, maximizing student-faculty interaction, involving students in active learning, and setting high expectations ${ }^{[26]}$. There is a positive impact of collaborative learning ${ }^{[27,28]}$, blended learning ${ }^{[29]}$, shared-learning experiences ${ }^{[30,31]}$, and technologies ${ }^{[32-36]}$ for improving the engagement of students and development of capabilities. Students reported increased engagement in self-directed clinical learning activities like e-learning ${ }^{[37]}$ and web based learning ${ }^{[38]}$ for developing critical reasoning processes, and conveyed that learning was more dynamic and active compared to the learning experienced in the conventional curricula ${ }^{[35]}$.

There was a positive attitude and relationship between the use of active learning and student engagement in the nursing course content using experiential learning activities such as problem solving, class discussion and research projects compared with those using more traditional lecture style strategies ${ }^{[39]}$. Nursing students engaged in shared learning opportunities and reported thinking about the course material more deeply compared to other students in the conventional courses using memorization or rote learning. Team learning was evaluated among baccalaureate nursing students with the STROBE Classroom Observation Tool to measure levels of student engagement during various classroom activities ${ }^{[40]}$. Students in team-learning environments were on task more than $50 \%$ of the class time, and engaged in instructional activity $84 \%$ of the time. Learner-to-learner engagement was the predominant engagement behaviour observed. Students revealed that they valued learning through discussion and listening to other points of view and identified this with critical thinking defined as cognitive skills of analyzing, applying standards, discriminating, information seeking, logical reasoning, predicting, and transforming knowledge ${ }^{[41]}$ and problem solving. Effectiveness of narrative-based interactive scenarios on learning outcomes among critical care and final year nursing students showed improved reasoning, decision making and learning outcomes in the learning environment ${ }^{[42]}$.

\subsection{Theoretical framework}

The conceptual model is based on Astin's theory of involvement ${ }^{[43]}$ describing engagement as the amount of physical and psychological energy a student devotes to educational experiences (Figure 1). Students engage in classes, clinical, study together, and interact with faculty and peers and learn by engaging in academic activities ${ }^{[44]}$. In this study inputs refer to the characteristics of student or demographic variables like gender, age, program, cohort, cumulative grade point average (cGPA), semester GPA (sGPA) and sibling studying in the university. Environment refers to faculty, peers, and educational experiences the student is exposed to in undergraduate nursing. It includes student peer group and faculty characteristics, curricular measures, and measures of engagement in active learning and educational activities in the class and clinical learning environments. Outcomes refer to the student's characteristics after exposure to the environment or outcomes (affective or cognitive). Cognitive learning outcomes include knowledge, critical thinking and academic achievement ${ }^{[41]}$. Cognitive behavioural learning outcomes include development of capabilities and level of educational attainment. Affective or emotional learning outcomes include values, attitudes or beliefs and satisfaction with the theory or clinical courses and curriculum experience. Intellectual processes, working together and teaching for understanding are basic elements of developing capabilities among students ${ }^{[45]}$.

In this study student engagement refers to the active and direct involvement of nursing students in learning through interaction with teachers to achieve the course outcomes in the class or clinical environment. The amount of learning or 
development is directly proportional to the quality and quantity of student engagement in collaborative clinical education ${ }^{[46]}$. The focus is primarily on cognitive, attitudes and behaviours that influence or describe student engagement (what the student does and how he or she behaves). These factors in the study are background variables, socializing environment, communication between the student and agents in the environment, the student's assessment of the communication, and the student's intention or decision to engage. As a student experiences engagement he or she develops his capabilities through cognitive, emotional and behavioural learning which are influenced by the student's background characteristics and the psychological and social aspects of engagement ${ }^{[47,48]}$.

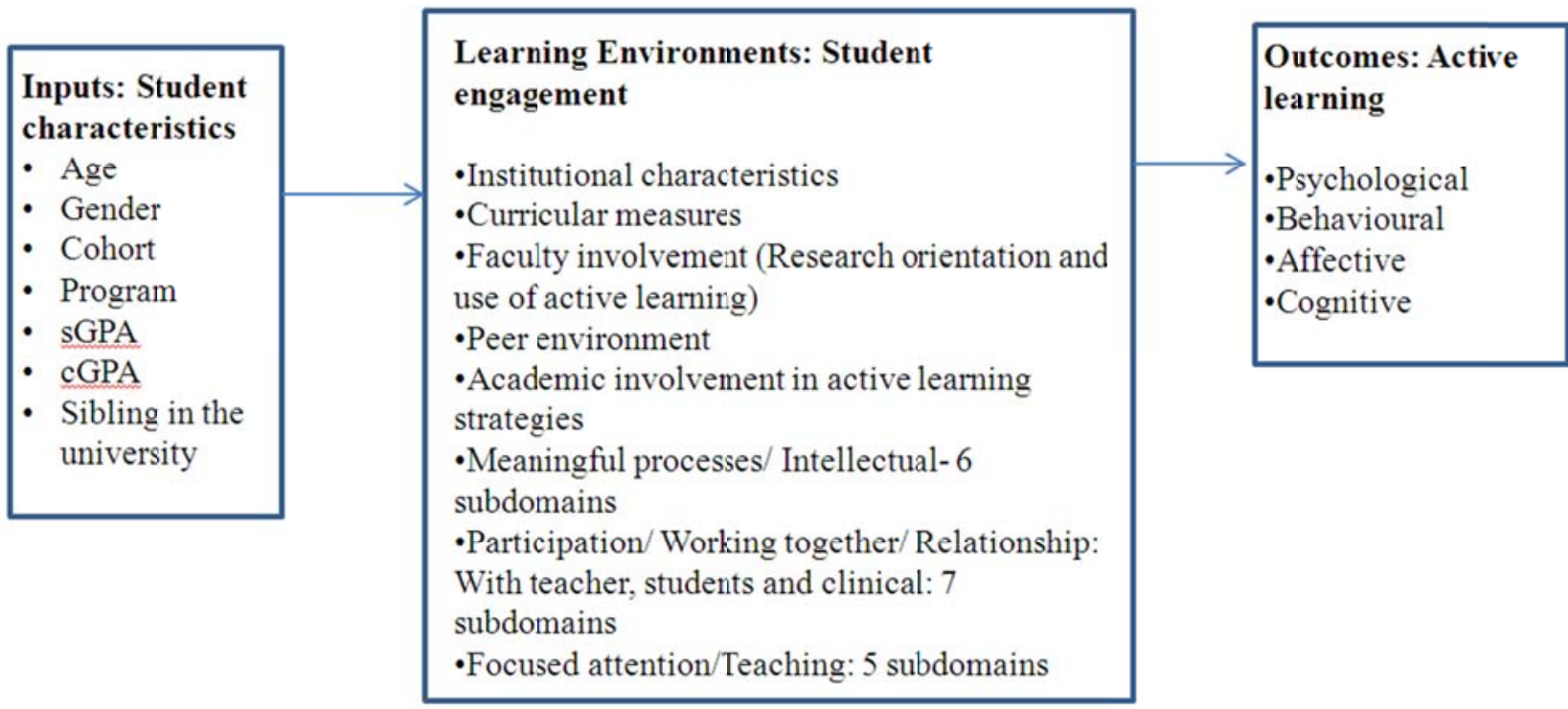

Figure 1. Student engagement and active learning in the learning environment (Astin's Theory of Involvement)

\section{Method}

\subsection{Design}

An exploratory cross-sectional research design was used to assess nursing student engagement in the learning environment for improved learning outcome in the undergraduate curriculcum.

\subsection{Setting, sample and inclusion criteria}

Sample size was determined using $\mathrm{G}^{*}$ Power software using chi-square for goodness of fit test, and contingency table ${ }^{[49]}$. The sample size was calculated at a power of $95 \%$ using $5 \%$ level of significance with a medium effect size of 0.3 with maximum 6 df with alpha $5 \%$. The total sample size was 232, assuming a 5\% attrition rate, 250 students were recruited. All the students were informed of the study and those who were willing to participate in the study were recruited in 2010 . The eligibility criteria were completion of $50 \%$ of the credits and 2 clinical courses in the undergraduate curriculum. The nursing students registered in level 1-4 of the nursing program or not exposed to clinical courses were not included in the study.

\section{Instrument}

A review of literature ${ }^{[50-52]}$ and instruments ${ }^{[13]}$ regarding perceptions of student engagement in teaching-learning was done. National and college surveys of student engagement ${ }^{[53]}$ across universities (Australia, Queensland, California, 
Indiana, Texas, Washington, Nevada, Michigan) and Langley's revise student engagement index ${ }^{[54]}$ were studied. The Student Engagement Questionnaire (SEQ) developed by David Kember and Doris Leuing ${ }^{[19]}$ was found to be appropriate for the study. SEQ has 3 domains (Meaningful Processes, Participation and Focused Attention) and 17 subdomains with 35 items ${ }^{[5,56]}$. All items were scored on a 5 -point Likert scale ranging from $1=$ 'strongly disagree' to $5=$ 'strongly agree'. Meaningful processes or Intellectual domain has 6 subdomains like Critical thinking ( 2 items), Creative thinking ( 2 items), Self-managed learning ( 2 items), Adaptability ( 2 items), Problem solving (2 items) and Computer literacy (2 items). Participation/ Working together/ Relationship domain had 7 domains like Communication skills (2 items), IP skills and group work ( 2 items), Active learning ( 2 items), Feedback to assist learning ( 2 items), Relationship between teachers and students ( 2 items), Relationship with other students ( 2 items) and Cooperative learning ( 2 items). Focused attention or Teaching has 4 domains like Assessment ( 3 items), Workload ( 2 items), Coherence of curriculum ( 2 items) and Teaching for understanding (2 items). Demographic characteristics has 7 items like age, gender, cohort, program of study, cGPA, sGPA, and sibling studying in the same university. Content validity of the SEQ instrument was established by three nurse educators and educational experts. Reliability of the tool was established with coefficient of internal consistency computed by Cronbach-alpha was 0.82 .

Table 1. Demographic charactersitics and level of significance among nursing students $\mathrm{N}=250$

\begin{tabular}{|c|c|c|c|c|c|}
\hline Category & Characteristics & Frequency & Percentage & $\begin{array}{l}\text { Chi-square } \\
\text { value }\end{array}$ & $p$ value \\
\hline \multirow{2}{*}{ Age (years) } & Below 25 & 195 & 78.00 & \multirow{2}{*}{9.127} & \multirow{2}{*}{$0.028^{*}$} \\
\hline & More than 25 & 55 & 22.00 & & \\
\hline \multirow{2}{*}{ Gender } & Male & 50 & 20.00 & \multirow{2}{*}{7.246} & \multirow{2}{*}{0.064} \\
\hline & Female & 200 & 80.00 & & \\
\hline \multirow{5}{*}{ Cohort } & 2004 & 36 & 14.40 & \multirow{5}{*}{40.546} & \multirow{5}{*}{$0.006^{*}$} \\
\hline & 2005 & 67 & 26.80 & & \\
\hline & 2006 & 50 & 20.00 & & \\
\hline & 2007 & 52 & 20.80 & & \\
\hline & 2008 & 45 & 18.00 & & \\
\hline \multirow{2}{*}{ Program of Study } & Regular BSN & 200 & 80.00 & \multirow{2}{*}{7.025} & \multirow{2}{*}{0.071} \\
\hline & NDGP & 50 & 20.00 & & \\
\hline \multirow{4}{*}{ Cumulative GPA } & $\mathrm{A}$ & 42 & 16.80 & \multirow{4}{*}{11.961} & \multirow{4}{*}{0.216} \\
\hline & $\mathrm{B}$ & 117 & 46.80 & & \\
\hline & $\mathrm{C}$ & 80 & 32.00 & & \\
\hline & $\mathrm{D}$ & 11 & 4.40 & & \\
\hline \multirow{2}{*}{ Siblings in the University } & No & 187 & 74.80 & \multirow{2}{*}{3.876} & \multirow{2}{*}{0.275} \\
\hline & Yes & 63 & 25.20 & & \\
\hline
\end{tabular}

Note. Bacheleor of science in nursing (BSN), Nursing diploma graduate program (NDGP), Grade point average (GPA), ${ }^{*} p<0.05$

\subsection{Ethical considerations}

The study was approved by the Research and Ethics Committee, College of Nursing at Sultan Qaboos University. All the students of each cohort were involved in the study. All the students were provided written information explaining the study purpose in a covering letter, instructions regarding the questionnaire and participants rights. A written informed consent was taken from all participants who willingly participated in the study. The students filled the questionnaire, sealed it in an envelope and dropped it in a locked box. Anonymity of the participants and confidentiality of the data was maintained. 


\subsection{Data collection and analysis}

The data was double checked, entered and coded in the SPSS 19 version. The open responses were analyzed with the software program NVivo ${ }^{[57]}$. Analytical coding was used to interpret and reflect on the meaning of the text within the interview transcripts. Text searches in NVivo 8 enabled to search for the codes that appear significant across the data or in any particular category as it brings together material for further consideration and analysis ${ }^{[10]}$. Thematic content analysis and constant comparative techniques was done to make inferences from text or other media that are valid and replicable ${ }^{[58,59]}$. Steps included reading through the transcripts several times, identifying significant statements (i.e., meaning units), clustering these into subcategories and categories, and finally identifying underlining threads or themes related to meaningful process, participation and focused attention. The inter-coder reliability was done using double data entry and double coding. Inter-rater reliability was protected by independent analysis by each investigator who read through the responses a minimum of three times to become immersed in the data. The codes were grouped together in conceptual categories that shared similar patterns or related content; then the conceptual categories were inductively abstracted into larger conceptual entities labeled as various student engagement themes.

Table 2. Nursing student engagement domains in the learning environment $(\mathrm{N}=250)$

\begin{tabular}{llll}
\hline Domains & Student engagement subdomains & Mean score & Mean score \\
\hline Meaningful & Critical thinking & 3.61 & \\
& Crocesses & 3.77 & 3.92 \\
& Self-managed learning & 3.98 & \\
& Adaptability & 3.94 & \\
& Problem solving & 3.98 & \\
& Computer literacy & 4.24 & \\
Participation & Communication skills & 3.98 & 3.95 \\
& Interpersonal skills and group work & 3.67 & \\
& Active learning & 4.33 & \\
& Feedback to assist learning & 4.07 & \\
& Relationship between teachers and students & 4.24 & \\
& Relationship with other students & 4.05 & 3.94 \\
Focused & Cooperative learning & 3.31 & \\
Attention & Teaching for understanding & 4.17 & \\
& Assessment & 4.18 & \\
& Workload & 3.67 & 3.76 \\
\hline
\end{tabular}

\section{Results}

\subsection{Demographic characteristics}

Majority of the students were less than 25 years (78\%), females (80\%) and pursuing BSN degree (80\%) among the 250 students (see Table 1). Nearly quarter percentage of the students belonged to each cohort group 2005 (26.8\%), 2006 and 2007 (20\% each). There was equal representation of students in each cohort with higher percentage belonging to cohort 2005 (26.8\%). Less than half percentage of thest students had cumulative Grade Point Average (cGPA) of B grade (46.8\%) while few had C (32\%) and A (16.8\%). Most students had siblings stuyding in the same university (74.8\%). 
Table 3. Frequency and percentage of nursing student engagement subdomains $(\mathrm{N}=250)$

\begin{tabular}{|c|c|c|c|c|c|c|c|c|c|c|c|}
\hline Domains & $\begin{array}{l}\text { Engagement } \\
\text { subdomains }\end{array}$ & $\begin{array}{l}\text { Strongly } \\
\text { disagree } \\
\text { (1) }\end{array}$ & $\%$ & $\begin{array}{l}\text { Disagree } \\
\text { (2) }\end{array}$ & $\%$ & $\begin{array}{l}\text { Neither } \\
\text { agree nor } \\
\text { disagree } \\
\text { (3) }\end{array}$ & $\%$ & Agree (4) & $\%$ & $\begin{array}{l}\text { Strongly } \\
\text { agree } \\
\text { (5) }\end{array}$ & $\%$ \\
\hline \multirow{6}{*}{$\begin{array}{l}\text { Meaningful } \\
\text { Processes }\end{array}$} & Critical thinking & 0 & 0 & 47 & 19 & 41 & 16 & 125 & 50 & 37 & 15 \\
\hline & Creative thinking & 0 & 0 & 32 & 13 & 44 & 18 & 124 & 50 & 50 & 20 \\
\hline & $\begin{array}{l}\text { Self-managed } \\
\text { learning }\end{array}$ & 3 & 1 & 5 & 2 & 44 & 18 & 139 & 56 & 59 & 24 \\
\hline & Adaptability & 0 & 0 & 28 & 11 & 33 & 13 & 116 & 46 & 73 & 29 \\
\hline & Problem solving & 0 & 0 & 13 & 5 & 23 & 9 & 169 & 68 & 45 & 18 \\
\hline & Computer literacy & 0 & 0 & 6 & 2 & 15 & 6 & 143 & 57 & 86 & 34 \\
\hline \multirow{7}{*}{ Participation } & $\begin{array}{l}\text { Communication } \\
\text { skills }\end{array}$ & 0 & 0 & 28 & 11 & 20 & 8 & 132 & 53 & 70 & 28 \\
\hline & $\begin{array}{l}\text { Interpersonal } \\
\text { skills and group } \\
\text { work }\end{array}$ & 0 & 0 & 58 & 23 & 13 & 5 & 132 & 53 & 47 & 19 \\
\hline & Active learning & 0 & 0 & 9 & 4 & 14 & 6 & 115 & 46 & 112 & 45 \\
\hline & $\begin{array}{l}\text { Feedback to assist } \\
\text { learning }\end{array}$ & 0 & 0 & 10 & 4 & 21 & 8 & 161 & 64 & 58 & 23 \\
\hline & $\begin{array}{l}\text { Relationship } \\
\text { between teachers } \\
\text { and students }\end{array}$ & 3 & 1 & 3 & 1 & 9 & 4 & 152 & 61 & 83 & 33 \\
\hline & $\begin{array}{l}\text { Relationship with } \\
\text { other students }\end{array}$ & 0 & 0 & 20 & 8 & 7 & 3 & 164 & 66 & 59 & 24 \\
\hline & $\begin{array}{l}\text { Cooperative } \\
\text { learning }\end{array}$ & 10 & 4 & 81 & 32 & 13 & 5 & 113 & 45 & 33 & 13 \\
\hline \multirow{4}{*}{$\begin{array}{l}\text { Focused } \\
\text { Attention }\end{array}$} & Assessment & 0 & 0 & 9 & 4 & 16 & 6 & 147 & 59 & 78 & 31 \\
\hline & Workload & 18 & 7 & 34 & 14 & 15 & 6 & 129 & 52 & 54 & 22 \\
\hline & $\begin{array}{l}\text { Coherence of } \\
\text { curriculum }\end{array}$ & 6 & 2 & 35 & 14 & 14 & 6 & 153 & 61 & 42 & 17 \\
\hline & $\begin{array}{l}\text { Teaching for } \\
\text { understanding }\end{array}$ & 0 & 0 & 7 & 3 & 21 & 8 & 145 & 58 & 77 & 31 \\
\hline
\end{tabular}

\subsection{Student engagment processes}

Among the 17 student engagement (SE) components, seven (7) items measured engagement behaviours (cognitive) and ten (10) measured engagement attitudes (emotional) (see Table 2). 46\%-68\% of the of the students scored high mean scores in the 17 SE subdomains across the 3 domains of SE (Meaningul processes, Participation and Focused attention). Increased number of nursing students showed critical thinking (3.61), creative thinking (3.77) and problem solving (3.98) abilities. Participation category mean score (3.95) was higher compared to the Focused attention mean (3.94) and Meaningul processes mean (3.92).

Students scored high mean scores in all the components of the 3 dimensions of SE. Computer literacy (4.24) had the highest mean score compared to the other components of the Meaningful processes of SE. Relationship between teachers and students (4.24), Feedback to assist teaching (4.07) and Relationship with other students (4.05) were among the higher mean scores for Participation in SE. Assessment (4.18) and Teaching for understanding (4.17) had higher mean scores compared to other SE components of Focused attention. 
Majority of the students agreed that they engaged in Meaningful processes (46\%-68\%) compared to Participation (45\%-66\%) and Focused Attention (52\%-61\%) (see Table 3). Some of the students strongly agreed with Participation (13\%-45\%), Meaningful processes (15\%-34\%) and Focused Attention (17\%-31\%).

\subsection{Association between student engagement and demographic characterisitcs}

There was a significant association between cohort, as well as siblings studying in the same university and all the SE domains of meaningful processes, participation and focused attention (see Table 4). Co-operative learning and Workload was highly associated with all the demographic characteristics. Problem solving was associated with cGPA $(p<0.001)$ and Co-operative learning with age $(p<0.014)$ and program $(p<0.034)$. Teaching for understanding was associated with gender $(p<0.039)$ and Workload was associated with age $(p<0.05)$ and program $(p<0.042)$.

Table 4. Association between demographic characteristics and student engagement domains

\begin{tabular}{|c|c|c|c|c|c|c|c|}
\hline Engagement components & & Age & Gender & Cohort & Program & Grades & $\begin{array}{l}\text { Sibling in } \\
\text { university }\end{array}$ \\
\hline \multicolumn{8}{|l|}{ Meaningful Processes } \\
\hline Critical thinking & 1 & 0.642 & 0.167 & $0^{*}$ & 0.469 & 0.12 & $0.001 *$ \\
\hline Creative thinking & 2 & 0.064 & 0.125 & $0^{*}$ & 0.269 & 0.14 & 0.09 \\
\hline Self-managed learning & 3 & 0.111 & 0.112 & $0^{*}$ & 0.267 & 0.235 & $0.023^{*}$ \\
\hline Adaptability & 4 & 0.265 & 0.112 & $0.003^{*}$ & 0.152 & 0.201 & $0^{*}$ \\
\hline Problem solving & 5 & 0.802 & 0.197 & $0.033^{*}$ & 0.608 & $0.001^{*}$ & 0.236 \\
\hline Computer literacy & 6 & 0.419 & 0.54 & $0.007^{*}$ & 0.17 & 0.065 & $0.001^{*}$ \\
\hline \multicolumn{8}{|l|}{ Participation } \\
\hline Communication skills & 7 & 0.673 & 0.142 & $0.043^{*}$ & 0.763 & 0.893 & $0.021^{*}$ \\
\hline $\begin{array}{l}\text { Interpersonal skills and group } \\
\text { work }\end{array}$ & 8 & 0.218 & 0.06 & $0^{*}$ & 0.27 & 0.822 & $0.002^{*}$ \\
\hline Active learning & 9 & 0.407 & 0.428 & $0^{*}$ & 0.305 & 0.181 & $0^{*}$ \\
\hline Feedback to assist learning & 10 & 0.537 & 0.124 & $0.005^{*}$ & 0.647 & 0.388 & $0.002^{*}$ \\
\hline $\begin{array}{l}\text { Relationship between teachers } \\
\text { and students }\end{array}$ & 11 & 0.348 & 0.235 & $0.01^{*}$ & 0.138 & 0.065 & $0.001^{*}$ \\
\hline $\begin{array}{l}\text { Relationship with other } \\
\text { students }\end{array}$ & 12 & 0.535 & 0.075 & $0.023^{*}$ & 0.593 & 0.95 & $0.014^{*}$ \\
\hline Cooperative learning & 13 & $0.014^{*}$ & 0.252 & $0^{*}$ & $0.034^{*}$ & 0.126 & $0^{*}$ \\
\hline \multicolumn{8}{|l|}{ Focused Attention } \\
\hline Teaching for understanding & 14 & 0.79 & $0.039^{*}$ & $0^{*}$ & 0.646 & 0.393 & $0^{*}$ \\
\hline Assessment & 15 & 0.345 & 0.217 & $0^{*}$ & 0.486 & 0.248 & $0^{*}$ \\
\hline Workload & 16 & 0.05 & 0.125 & $0^{*}$ & $0.042^{*}$ & 0.307 & $0^{*}$ \\
\hline Coherence of curriculum & 17 & 0.199 & 0.153 & $0.002^{*}$ & 0.142 & 0.328 & $0.001^{*}$ \\
\hline
\end{tabular}

Pearson Chi-square ${ }^{*} p<0.05$, Asymp. Sig. (2-sided)

\subsection{Nursing student engagement perceptions}

There was evidence of a pattern of responses about how the students engaged in the learning environments and contributions to their learning based on individual learning preferences with examples of responses discussed below: 
Meaningful processes includes Critical thinking, Creative thinking, Self-managed learning, Adaptability, and Problem solving which are critical to learning. Students prefer both procedural and conceptual knowledge by engaging in clinical skills, observation, or hands-on practical experiences, more than books.

"I use my knowledge of basic sciences to relate to nursing assessment and management in the clinical units". (Critical thinking)

"Lectures, case scenarios, individual assignments and group discussions with pictures (illustration), clip art and videos help me remember and apply the concepts in my nursing care". (Creative thinking)

"I work on my clinical assignments using critical thinking and analyze the clinical situation and correlate with biomedical knowledge". (Self managed learning)

"I like browsing for evidence based care before presenting my clinical case. This helps me to prepare my clinical case, improve my self-confidence and ability to use information in the clinical unit". (Adaptability)

"I like the clinical activities that engage me in active learning, improve critical thinking process, communication skills and make me comfortable in managing my patient care". (Problem solving).

Participation/ Working together/ Relationship domain consisted of Communication skills, IP skills and group work, Active learning, Feedback to assist learning, Relationship between teachers and students, Relationship with other students and Cooperative learning. Students engage in discussion, debate, simulation, real life patient experiences, work relations, and clinical performance that translated into practice across the settings.

"It is important to understand, express and present and write my clinical information in detail. I try to read books, journals, discuss with my peers and teachers to enable me answer questions". (Communication skills)

"I liked the clinical experiences, they have helped me to see, understand and learn new things each day (from what I learn in the theory) and how to work with others as a team. It helps me think diversely and help me get along with others. I prefer to work in groups as it improves nursing care". (Interpersonal skills and group work)

"I like the clinical exposure to the various clinical units that have enabled me to have a wide range of experiences. This has provided opportunities to observe, interact, think and plan in different situations. We engage in relevant and active clinical learning and focus on various situations, how to handle, provide care and evaluate patient response, e.g. life threatening conditions. Clinical presentations required students to research a topic and initiate discussion. The teacher facilitates in-depth exploration of the topic through searching questions". (Active learning)

"Teacher provides feedback of clinical performance and presentations, group interaction and exams. She provides feedback after each test and assignment". (Feedback to assist teaching)

"Questioning techniques used by the teachers help me in going deeper into the subject, be more reflective and helps stimulate my thinking processes". (Relationship with teachers and students)

"While engaging in discussion in- and out-of-class or clinical we have an opportunity to get to know each other. Having group activities has also led to class coherence and continues in our study period. We get to know each other and learn how to work together in a cooperative way. Sometimes we interact with different cohorts and programs (regular and bridging) for projects and clinical practice". (Relationship with students) 
"In my initial clinical courses I was very poor in the subject. I had to take the help of my peers and discuss the cases after clinical. This helped me understand the subject and improve my memory. These discussions helped me to prepare my clinical presentations and focused care plans. This has definitely improved the quality of my learning, much better than learning on my own or going to the library". (Co-operative learning)

Focused attention or Teaching consisted of Teaching for understanding. Students recount diverse learning experiences and positive interactions with teachers through interdisciplinary approach and active learning strategies.

"In-depth explanation, group discussions, interactive activities, two-way communication with teachers helps me to engage in learning and use theoretical knowledge in understanding physiology, biochemistry and pharmacology for use in nursing care". (Teaching for understanding)

\section{Discussion}

Majority of the nursing students were below 25 years, females and pursuing regular BSN degree. $50 \%$ of the students had cGPA of 'B' grade while some had 'A' grade. Most of the student had siblings stuyding in the same university. Most of the students scored high mean scores in the 17 SE subdomains across the 3 domains of SE (Meaningul processes, Participation and Focused attention). More nursing students showed critical thinking, creative thinking and problem solving. These subdomains of meaningful processes requires a transition from 'learning for knowledge and comprehension' to 'learning through application-synthesis-evaluation' ${ }^{[60]}$. Participation category mean score was higher compared to the Focused attention and Meaningul processes. Living on campus, interaction with multicultural nursing fraternity have contributed towards student engagement. Computer literacy, Relationship between teachers and students, Feedback to assist teaching, Relationship with other students, Assessment and Teaching for understanding were among the higher mean scores compared to SE subdomains. Nursing students at the school of nursing are well-versed with the use of online information, educational and clinical updates with a 'spirit to inquire'. Teaching methods with learning preferences expedite knowledge transfer process while learning envrionments contextualize the concepts and practices learnt from textbooks and laboratory ${ }^{[61,62]}$.

Clinical reasoning, communication, learning for understanding, analyzing and conceptualizing, and student-teacher interaction foster two-way communication in the learning expereinces. These cognitive and behavioural learning skills required these students to maximize the resources available to make their clinical learning experiences wholesome. Students who engaged in more active learning perceived more engagement in learning and web learning ${ }^{[51,63,64]}$ and reported higher levels of capabiliites ${ }^{[12]}$. Focussed clinical teaching promoted individualized attention, effective feedback, implementation of best practices in accordance to the student's level of understanding in the class room and ability in the clinical learning envrionments. Teachers at the school of nursing promote working in groups, debates, dicsusison, constructive feedback, quesitoning, and interaction with faculty. Teachers engage students in problem solving, conditonal instructions and purposeful teaching related to academic content for improved outcome ${ }^{[50]}$.

When teaching-learning experiences are correlated to the real-world context, cognition processes are enhanced. Younger age group (below 25 years) students pursuing BSN in various cohorts was associated with the total SE mean scores showing more inclination towards engagement behaviours. Some of these students obtained higher cGPAs and sGPAs (B). These students live away from family, on-campus and study with peers leading to concentrated time and engagement in curricular activities. Male students demonstrated greater adaptabilty in the clinical units compared to their female counterparts. They are more inclined to be independent learners,though they engage less frequently in academically challenging activities compared to the female counterparts' ${ }^{[65,66]}$.

There was a significant association between cohort as well as siblings studying in the same university and all the $17 \mathrm{SE}$ subdomains. Co-operative learning and Workload was highly associated with all the student characteristics among NDGP program. These students learn in groups, share information and have mutual exhange of knowledge and experiences. 
Senior students have been engaged for long periods in clinical learning and academic tasks ${ }^{[12]}$. NDGP students had higher mean scores in cooperative learning and workload. Their affinity to workload is related to the rigorous, intensive and structured curriculum within a two-year period. Students who have prior learning experience have demonstrated higher levels of student engagement ${ }^{[65,67,68]}$.

Problem solving and teaching for understanding was associated with higher grades, higher cohorts. Students with C grades reported high mean engagement scores because they showed increased engagement to improve their grades ${ }^{[56]}$. Students of cohort 2006 and higher who have completed more curricula and clinical courses tend to focus more on graduation and expectant role transition and are not as engaged in learning activities as their sophomore and junior peers ${ }^{[56]}$. Active learning promotes student engagement among nursing students that have positive effects on problem solving, critical thinking, and persistence ${ }^{[15]}$.

Students of cohort 2009 had higher SE participation subdomain scores in self-managed learning, adaptability, communication skills, feedback to assist learning, cooperative learning and coherehnce to curriculum. This is attrtibuted to student engagement in cognitive, emotional and behavioural learning expereinces in undergraduate curriculum, academic life, extra-curricular activities, sense of responsbility, exposure to multi-cultural nurse educators and international community. Engagement in communication and teaching for understanding had higher participation scores among students in Cohort 2008. This cohort was exposed to Fundamentals of Nursing and Health Assessment courses which expected them to apply the theoretical knowledge and communicate with peers and nurse educators in the simulated learning laboratory environments that "actively involve learners in applying the content of the lessons" [56]. Students of cohort 2005 were engaged in clinical reasoning, computer literacy and assessment in the learning environment to keep pace with the curricular expectations and initial fear and anxiety in the laboratory and clinical environments. The graduating cohort in the final courses like the advanced clinical nursing course, worked more independently with nurse preceptors and demonstrated higher subdomain scores in problem solving, relationship between teachers and students and relationship with other students. Senior graduates develop skills in talking through material with peers, listening with real skill, knowing how to build trust in a working relationship, and providing leadership to group efforts ${ }^{[69]}$.

Nursing students who had sibling(s) studying in the University engaged in more cognitive learning (critical thinking, adaptability), participation (communication skills, interpersonal skills \& group work, feedback to assist learning, relationship with other students) and focused attention (workload) domain scores dominated by 'Participation' domain with presence of siblings in the University. Meaningful Processes (self managed learning \& computer literacy) and Focused Attention (Assessment \& Coherence to curriculum) were prevalent among students without siblings in the University, highlighting the need to rely more on individual factors to surpass the learning standards. Students actively involved in patient care ${ }^{[70]}$ valued faculty support and learning opportunities to practice clinical and communication skills ${ }^{[71,72]}$.

\section{Conclusion}

In this study the outcomes (such as GPA, academic achievement measures) are influenced by inputs or student characteristics (such as gender, age, GPA) and the engagement process (cognitive, emotional and behavioural learning). Environments such as institutional characteristics, curricula, faculty and peer environment, as well as individual experiences of students in college mediate the relationship between inputs and outcomes. Students engage at many levels (e.g., involvement with peer groups, faculty, in academic and clinical work) to enhance almost all aspects of cognitive, emotional and behavioural learning and academic performance. The use of active learning e.g. presentations in class, taking short answer exams and working on independent clinical projects encourages student centered learning. In essence, the quality and quantity of engagement influenced the amount of learning that takes place. A crucial factor in the development of the undergraduate student is the degree to which "the student is actively engaged or involved in the college experience" ${ }^{[73]}$. The predictors of Student Engagement behaviours were age, cohort, program, grades and siblings in the 
university. These factors are a positive reinforcement to improve teaching-learning processes. If faculty facilitate students with training and practice in the behavioural and social skills required to work cooperatively with others, they will have the satisfaction of knowing they have helped prepare students for a world where they will need to coordinate their efforts with others on the job, skillfully balance personal relationships, and be contributing members of their communities and society ${ }^{[65,67]}$.

Students preferred small group discussions which helped them to develop critical thinking, problem solving abilities and interact with the teachers. Students are actively engaged in thinking, generating their opinions and answers and voicing their views with feedback from the teachers. For discussions to be successful in nurturing capabilities, the teachers have to facilitate and stimulate discussions through questioning and guiding the responses. In the clinical environment students preferred to develop behavioural competencies through self-practice, ability to search for appropriate knowledge and information. This provides practice in learning by oneself, which helped to develop emotional and self-managed learning abilities. Students devote increased time to clinical assignments, case studies, health education and evidence based projects to strengthen their cognitive capabilities. By encouraging students to think, reason, make decisions, judge and evaluate independently, they engage in learning activities in the class room and clinical environments. These students on graduation will be lifelong or self-managed learners. Good teacher-student relationships, a high degree of interaction and engagement in active learning help to promote understanding within the cohorts, which leads to positive peer-student relationships and facilitate learning among students ${ }^{[74]}$.

The present study shows that teachers who facilitate student engagement through discussions, presentations, defense, and nursing debates are more likely to engage students in active learning. The focus of students' perception of engagement in critical thinking, participation and attention was their ability to make judge and interpretations, and not necessarily accept the perspective of the teacher. Problem-solving ability was nurtured through practice and asking students to solve problems in the theoretical and clinical scenarios. Communication skills was enhanced through student's presentations and meaningful discussions. Interpersonal skills were practiced when students worked together in teams. For these higher capabilities to develop they have to be integrated in various courses like communication, psychosocial, psychology and evidence based, biomedical and clinical courses in curriculum.

\section{I mplications for nursing education}

Cognitive learning through meaningful processes, such as critical and creative thinking, adaptability, the ability to solve ill-defined problems and the ability to manage one's own learning are seen as important in nursing education. The benefit of good student-student relationships and emotional learning came through the formation of study groups which try to make sense together of difficult concepts. Students develop a better understanding of concepts by working together out-of class or clinical using an engager approach ${ }^{[74]}$. A variety of assessment and behavioural learning methods, such as formative and summative exams, assignments, oral exams, clinical skills exams, writing nursing process, case study and presentations are required in the curriculum. Assessment and evaluation are important as they have a strong influence on the learning approaches students adopt ${ }^{[75]}$. The design of the nursing curriculum should integrate student engagement processes (cognitive, emotional and behavioural learning) to enhance necessary generic and professional capabilities among undergraduate nursing students.

\section{Acknowledgements}

The authors gratefully acknowledge the content experts and language editors for valuable suggestions during the study.

\section{Authors' contributions}

MSD, RV and KSN conceived of the study conception and design, data collection/ acquisition, and provided analysis and interpretation. MSD, KSN and CI participated in the analysis and interpretation and first draft. AA conducted the data 
collection and data entry. All the authors drafted the manuscript, provided critical revision of manuscript for important intellectual content and provided final approval of version to be submitted.

MSD-Melba Sheila D'Souza, CI-Chandrani Isac, KSN-KarkadaSubrahmanyaNairy, RV-Ramesh Venkatesaperumal, AA-Anandhi Amirtharaj.

\section{Conflict of competing interests}

There are no organisations or communities with conflict of interest or coveting interests related to the study. The co-authors declare that they have no competing interests.

\section{Funding statement}

The study has been self-financed.

\section{References}

[1] McDermott PA. Mordell M. Stolzfus JC. The organization of student performance in American schools: discipline, motivation, verbal learning, and nonverbal learning. J Educ. Psychol. 2001; 93(1): 65-76.

[2] Liaupsin CJ, Umbreit J, Ferro JB, Urso A, Upreti G. Improving academic engagement through systematic, function-based intervention. Education and Treatment of Children. 2006; 29(4): 572-589.

[3] Pressley M, Gaskins IW, Solic K, Collins S. A portrait of Benchmark School: How a school produces high achievement in students who previously failed. Journal of Educational Psychology. 2006; 98(2): 282-306.

[4] Greenwood CR, Horton BT, Utley CA. Academic engagement: Current perspectives on research and practice. School Psychology Review. 2002; 31(3): 328-349.

[5] Legters N, Balfanz R, McPartland J. Solutions for failing high schools: Converging visions and promising models. Washington, DC: Office of Vocational and Adult Education. 2002.

[6] Perie M, Moran R, Lutkus AD. The nation's report card. NAEP 2004 Trends in academic progress: Three decades of student performance in reading and mathematics. Washington, DC: U.S. Department of Education Institute of Education Sciences; 2005; 464.

[7] Popkess A, McDaniel AM. Baccalaureate nursing student's responses to the National Survey of Student Engagement. Unpublished Manuscript. Manuscript submitted for publication. 2007.

[8] Henderson S, Happell B. Martin T. So what is so good about clinical experience? A mental health nursing perspective. Nurse Education in Practice. 2007; 7(1): 164-172.

[9] Ahlfeldt S, Mehta S, Sellnow T. Measurement and analysis of student engagement in university classes where varying levels of PBL methods of instruction are in use. Higher Education Research and Development. 2005; 24(1): 5-20.

[10] Kelly PA, Haidet P, Schneider V, Searle N, Seidel CL, Richards B. A comparison of in-class learner engagement across lecture, problem-based learning and team learning using the STROBE classroom observation tool. Teaching and Learning in Medicine. 2005; 17(2): 112-118.

[11] Carini RM, Kuh G, Klein SP. Student engagement and student learning: Testing the linkages. San Diego, CA: American Educational Research Association; 2004.

[12] Kuh G, Kinzie J, Schuh JH, Whitt EJ, Associates. Student success in college: Creating conditions that matter. San Francisco: Jossey-Bass. 2005.

[13] Pascarella ET. Using student self-reported gains to estimate college impact: A cautionary tale. Journal of College Student Development. 2001; 42(5): 488-492.

[14] Kushman JW, Sieber C, Heariold-Kinney P. This isn't the place for me: School dropout. In D. Capuzzi \& D. R. Gross (Eds.), Youth at risk: A prevention resource for counselors, nurse educators, and parents (3rd ed). Alexandria, VA: American Counseling Association. 2000.

[15] Braxton JM, Milem JF, Sullivan AS. The influence of active learning on the college student departure process: Toward a revision of Tinto's theory. Journal of Higher Education. 2000; 71(5): 569-590.

[16] Kuh GD. Assessing what really matters to student learning: Inside the National Survey of Student Engagement. Change. 2001; 33(3): 10-17.

[17] Kuh G. The national survey of student engagement: Conceptual framework and overview of psychometric properties. Bloomington, IN: Indiana University Center for Postsecondary Research and Planning. 2002; 1-26. 
[18] Yazzie-Mintz E. Voices of students on engagement: A report on the 2006 high school survey of student engagement. Bloomington, IN: Center for Evaluation and Education Policy. 2006.

[19] Kember D, Leung DYP. The impact of the teaching and learning environment on the development of generic capabilities needed for a knowledge-based society. Learning Environments Research. 2005b; 8(3): 245-266.

[20] American Association of Colleges of Nursing. The essentials of baccalaureateeducation for professional nursing practice. Washington, DC: Author; 1998.

[21] American Association of Colleges of Nursing. Hallmarks of the professional nursing practice environment [Internet]. 2008 August 18[cited 2002]. Available from http://www.aacn.nche.edu/Publications/positions/hallmarks.htm

[22] Carr S. A framework for understanding clinical reasoning in community nursing. J. Clin. Nursing. 2004; $13(7): 850-857$.

[23] Everson HT, Millsap RE. Beyond individual differences: Exploring school effects on SAT scores. Educational Psychologist. 2004; 39(3): 157-172.

[24] Wenglinsky H. The link between teacher classroom practices and student academic performance. Education Policy Analysis Archives. 2002; 10(12).

[25] Patterson Johnson J, Mighten A. A comparison of teaching strategies: Lecture notes combined with structured group discussion versus lecture only. Journal of Nursing Education. 2005; 44(7): 319-322.

[26] Godefrooij MB, Diemer AD, and Scherpbie AJJA. Students' perceptions about the transition to the clinical phase of a medical curriculum with preclinical patient contacts; a focus group study. BMC Medical Education. 2010; 10: 28.

[27] Macdonald J. Assessing online collaborative learning: Process and product. Computers \& Education. 2003; 40(2): $377-391$.

[28] McConnell D. The experience of collaborative assessment in e-learning. Studies in Continuing Education. 2002; $24(1)$ : 73-92.

[29] Ginns P, Ellis R. Quality in blended learning: Exploring the relationships between on-line and face-to-face teaching and learning. Internet and Higher Education. 2007; 10(1): 53-64.

[30] Nelson KJ, Kift SM, Clarke JA. Expectations and realities for first year students at an Australian university. In: 11th Pacific Rim First Year in Higher Education Conference 2008. 2008 June 30-2 July[cited 2010 March]. Available from: http://www.fyhe.qut.edu.au/past_papers/papers08/FYHE2008/content/pdfs/6a.pdf

[31] Wood D. Real life access to second life worlds: The potential, the problems and the possibilities for a barrier-free future. The International Journal of Diversity in Organisations, Communities and Nations. 2009; 8(6): 139-148.

[32] Draper SW, Brown MI. Increasing interactivity in lectures using an electronic voting system. Journal of Computer Assisted Learning. 2004; 20(2): 81-94.

[33] Boulos M, Maramba I, Wheeler S. Wikis, blogs and podcasts: A new generation of web-based tools for virtual collaborative clinical practice and education. BMC Medical Education. 2006; 6(1): 41.

[34] Cabrera A, Crissman J, Bernal E, Nora A, Terenzini P, Pascarella ET. Collaborative learning: Its impact on college students' development and diversity. Journal of College Student Development. 2002; 43(3): 20-34.

[35] Cockrell KS, Caplow JAH, Donaldson JF. A context for learning: Collaborative groups in the problem-based learning environment. The Review of Higher Education. 2000; 23(4): 347-363.

[36] Tinto V. Moving from theory to action. In A. Seidman (Ed.) College student retention: Formula for student success. Washington DC: ACE \& Praeger. 2005.

[37] Moule P, Ward R, Lockyer L. Nursing and healthcare students' experiences and use of e-learning in higher education. Journal of Advanced Nursing. 2010; 66(12): 2785-2795.

[38] McNaught C, Lam P, Chan E, Yuen S, Ho E. Cultural aspects of adoption of innovation:A case study with implementing a lecture-recording system in a university in Hong Kong. Journal of the NUS Teaching Academy (JNUSTA). 2013.

[39] Pugsley KE, Clayton LH. Traditional lecture or experiential learning: Changing student attitudes. Journal of Nursing Education. 2003; 42(11): 520-523.

[40] Feingold CE, Cobb MD, Hernandez Givens R, Arnold J, Joslin S, Seller J. Student perceptions of team learning in nursing education. Journal of Nursing Education. 2008; 47(5): 214-222.

[41] Scheffer BK. Rubenfeld MG. A consensus statement on critical thinking in nursing. J Nurs Educ. 2000; 39(8): 352-60.

[42] Stranieri A, Yearwood J. Enhancing learning outcomes with an interactive knowledge-based learning environment providing narrative feedback. Interactive Learning Environments. 2008; 16(3): 265-281.

[43] Astin AW. Student involvement: A developmental theory for higher education. Journal of College Student Development. 1994; 24(2): 297-308.

[44] Henderson A, Winch S. Heel A. Partner, learn, progress: A conceptual model for continuous clinical education. Nurse Education Today. 2006a; 26: 104-109.

[45] Kember D. Best practice in outcomes based teaching and learning at the Chinese university of Hong Kong[Internet]. 2005. Available from: http://www.cuhk.edu.hk/clear 
[46] Henderson A, Heel A, Twentyman M. Lloyd B. Pre-test and post-test evaluation of students' perceptions of a collaborative clinical education model on the learning environment. Australian Journal of Advanced Nursing. 2006b; 23(3): 8-13.

[47] Bean JP. A conceptual model of college student engagement. Paper presented at the Association for the Study of Higher Education, Philadelphia, PA; 2005.

[48] McNaught C, Lam P, Cheng KF. Investigating relationships between features of learning designs and student learning outcomes. Education Tech Research Dev. 2012; 60: 271-286.

[49] Faul F, Erdfelder E., Lang A.-G. Buchner A. G*Power 3: a flexible statistical power analysis program for the social, behavioral, and biomedical sciences. Behaviour Research Methods. 2007; 39:175-191.

[50] McNaught C. The best of both worlds: Effective hybrid learning designs in higher education in Hong Kong. In R. Kwan, E. Young, \& B. White (Eds.). ICHL 2011, LNCS 6837 : 1-9. Heidelberg: Springer. Publication of Keynote address at the International Conference on Hybrid Learning 2011. 10-12 August 2011, Hong Kong. 2011.

[51] Moule P. E-learning for healthcare students: developing the communities of practice framework. Journal of Advanced Nursing .2006; 53(3): 370-380.

[52] Moule P, Ward R. Lockyer L. Issues with e-learning in nursing and health education in UK: are new technologies being embraced in the teaching and learning environments? Journal of Research in Nursing. 2010; 15(4):1-14.

[53] National Survey of Student Engagement. Promoting engagement for all students: The imperative to look within. Indiana University Center for Postsecondary Research[Internet]. Accessed November 1, 2008. Available from: http://www.nsse.iub.edu.

[54] Ruhe V. A toolkit for writing surveys to measure student engagement, reflective and responsible learning. The centre for teaching and learning services, University of Minnesota, Minneapolis. 2010.

[55] Kember D, Leung DYP. The influence of active learning experiences on the development of graduate capabilities. Studies in Higher Education. 2005a; 30(2): 155-170.

[56] Popkess AM and McDaniel A. 2010. Are Nursing Students Engaged in Learning? A Secondary Analysis of Data from the National Survey of Student Engagement. Nursing Educa tion Perspectives March / April Vol .32 No.2 89. 2007.

[57] NVivo qualitative data analysis software; QSR International Pty Ltd. Version 10, 2010.

[58] Krippendorff K: Content analysis: An introduction to its methodology. 2nd edition. Thousand Oaks, CA: Sage Publications; 2004.Kuh G, Kinzie J, Buckley J., Bridges B, Hayek J. Piecing together the student success puzzle: Research, propositions and recommendations. 2007: 32.

[59] Flinck A, Paavilainen E, Astedt-Kurki P: Survival of intimate partner violence as experienced by women. Journal of Clinical Nursing .2005; 1(4): 383-393.

[60] Kember D. Promoting student-centred forms of learning across an entire university. High Educ. 2009; 58: 1-13.

[61] Newton JM, Billett S. Jolly B. Ockerby CM. Lost in translation: barriers to learning in health professional clinical education. Learning in Health and Social Care. 2009; 8(4):315-327.

[62] Smith K, Clegg S, Lawrence E. Todd MJ. The challenges of reflection: Students learning from work placements. Innovations in Education and Teaching International . 2007; 44(1): 131.

[63] Moule P. Challenging the five-stage model for e-learning: a new approach. ALT-J. 2007; 15(1): 39-52.

[64] Woods R, Ebersole S. Becoming a 'communal architect' in the online classroom: Integrating cognitive and affective learning for maximum effect in web-based learning. Online Journal of Distance Learning Administration[Internet]. 2003; 4(1)[cited 2008 June 20]. Available from: http://www.westga.edu/ distance/ojdla/spring2003/woods61.htm.

[65] Kuh G, Kinzie J, Cruce T, Shoup R, Gonyea R. Connecting the Dots: Multi-faceted analyses of the relationships between student engagement results from the NSSE, and the institutional practices and conditions that foster student success. Bloomington, IN: Indiana University Center for Postsecondary Research.

[66] Pascarella ET, Terenzini PT. How college affects students: A third decade of research. San Francisco: Jossey-Bass; 2005.

[67] Delialioğlu Ö. Student Engagement in Blended Learning Environments with Lecture-Based and Problem-Based Instructional Approaches. Educational Technology \& Society. 2002; 15 (3): 310-322.

[68] Lundberg CA, Schreiner LA, Hovaguimian KD, Miller SS. First generation status and student race/ethnicity as distinct predictors of student involvement in learning. NASPA. 2007; 44(1): 57-67.

[69] Smith KA, Sheppard SD, Johnson DW, Johnson RT. Pedagogies of Engagement: Classroom-Based Practices. Journal of Engineering Education; 2005; 87-101.

[70] Hartigan-Rogers JA, Cobbett SL, Amirault MA, Muise-Davis ME. Nursing graduates' perceptions of their undergraduate clinical placement. International Journal of Nursing Education Scholarship. 2007; 4: 1-12.

[71] Freeth D. Fry H. Nursing students' and tutors' perceptions of learning and teaching in a clinical skills centre. Nurse Education Today. 2005; 25: 272-282. 
[72] Papp I, MarkkanenM, vonBonsdorff M. Clinical environment as a learning environment: student nurses' perceptions concerning clinical learning experiences. Nurse Education Today . 2003; 23(2): 262-268.

[73] Astin AW. Involvement in learning revisited: Lessons we have learned. Journal of College Student Development. 1996; 37(3): 123-133.

[74] Yan L, Kember D. The influence of the curriculum and learning environment on the learning approaches of groups of students outside the classroom. Learning Environments Research. 2003; 6(4): 285-307.

[75] Yan L, Kember D. Avoider and engager approaches by out-of-class groups: The group equivalent to individual learning approaches. Learning and Instruction. 2004; 14(1): 27-49. 